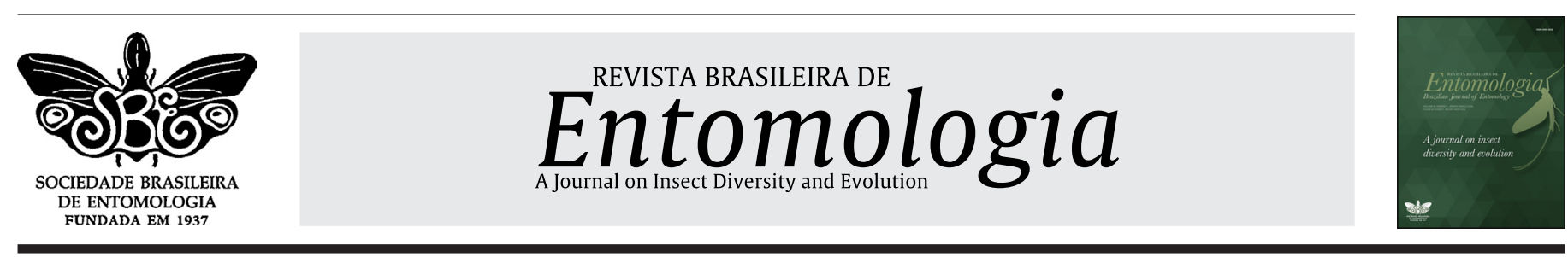

\title{
Sandfly fauna and behavior (Diptera: Psychodidae) in municipalities of the Mesoregion North Pioneer of Paraná, Brazil
}

\author{
Herintha Coeto Neitzke-Abreu ${ }^{1,2 *}$ (), Kárin Rosi Reinhold-Castro1, \\ Vanderson Carvalho Fenelon ${ }^{3}$, Rubens Massafera ${ }^{4}$, Jessé Truppel ${ }^{5}$, \\ Flávio Haragushiku Otomura ${ }^{6}$, Ueslei Teodoro ${ }^{1}$ \\ ${ }^{1}$ Universidade Estadual de Maringá, Programa de Pós-Graduação em Ciências da Saúde, Maringá, PR, Brasil. \\ ${ }^{2}$ Universidade Federal da Grande Dourados, Programa de Pós-Graduação em Ciências da Saúde, Dourados, MS, Brasil. \\ ${ }^{3}$ Universidade Estadual de Maringá, Programa de Pós-Graduação em Ciências Farmacêuticas, Maringá, PR, Brasil. \\ ${ }^{4}$ Secretaria de Estado de Saúde, Núcleo de Entomologia de Jacarezinho, Jacarezinho, PR, Brasil. \\ ${ }^{5}$ Ministério da Agricultura, Pecuária e Abastecimento, Curitiba, PR, Brasil. \\ ${ }^{6}$ Universidade Estadual do Norte do Paraná, Setor de Ciências Biológicas, Cornélio Procópio, PR, Brasil.
}

\section{A R T I C L E I N F O}

\section{Article history:}

Received 30 July 2020

Accepted 04 October 2020

Available online 06 November 2020

Associate Editor: Diana Grisales Ochoa

\section{Keywords:}

Domestic animals

Entomological surveillance

Vector control

\begin{abstract}
A B S T R A C T
The occurrence of cutaneous leishmaniasis (CL) in the municipalities of Jaboti, Japira, Pinhalão, and Tomazina in the North Pioneer of the State of Paraná, where this disease is endemic, prompted the investigation of sandfly fauna, their population changes throughout the year, and their behavior in and around human accommodation. In these municipalities, the collection of sandflies was conducted using Falcão traps from 7 pm to 6 am once a month. 32,994 sandflies, 18,442 males and 14,552 females, were collected and represented by the species Brumptomyia brumpti, Brumptomyia cunhai, Evandromyia correalimai, Evandromyia cortelezzii, Expapillata firmatoi, Micropygomyia ferreirana, Migonemyia migonei, Nyssomyia neivai, Nyssomyia whitmani, Pintomyia fischeri, Pintomyia monticola, Pintomyia pessoai, and Psathyromyia bigeniculata. Ny. neivai $($ SISA $=0.9808)$ predominated in Japira (46.9\%), Pinhalão (53.1\%), and Tomazina (38.9\%), while Ny. whitmani (SISA $=0.9423$ ) predominated in Jaboti (53.8\%). Most sandflies were captured in domestic animal shelters, with a peak in September. The high number of sandflies collected in domestic animal shelters, species richness, and presence of species involved in the epidemiology of CL reveal the need for permanent entomological surveillance in the municipalities mentioned. The use of phlebotomine control measures in these municipalities should be considered in conjunction with the anthropogenic actions that have resulted in changes to sandfly fauna and behavior.
\end{abstract}

The importance of sandflies as vectors of pathogens that cause leishmaniasis, bartonellosis, and arboviruses in the New World has expanded studies regarding the composition, behavior, and role of some species in the epidemiology of leishmaniasis. The diversity of environments and anthropic changes should be considered when it comes to adopting control measures for these insects, as the endemic areas of cutaneous leishmaniasis $(\mathrm{CL})$ are distinct and require measures according to the characteristics of each area (Teodoro et al., 2010).

In areas with intense anthropic transformations, where CL is endemic, the presence of residual native forests in rural and urban areas has sustained the population of sandflies and wild mammals, maintaining the Leishmania transmission cycle (Lima et al., 2002; Muniz et al., 2006; Almeida et al., 2013). The precarious hygiene conditions and proximity to shelters for domestic animals in human habitations next to modified residual forests, resulting from the colonization of the North Pioneer of Paraná and persisting until today, allow the cycle between wild mammals and sandflies to continue in the peridomicile, where there is great availability of food (Teodoro et al., 2001a, 2001b; Lima et al., 2002).

Of the CL cases reported in southern Brazil, approximately 95\% occurred in the Paraná State, with registration in most municipalities, including those in the northern region of Pioneer, justifying research on sandflies in endemic areas of this state (Brasil, 2018). Several studies have been conducted regarding the distribution of sandflies in Paraná (Membrive et al., 2004; Silva et al., 2008; Teodoro et al., 2010), but there remain many municipalities, including Jaboti, Japira, Pinhalão, and Tomazina, that have not been fully investigated regarding the composition of the sandfly fauna and the frequency of occurrence of these insects in human habitations and domestic animal shelters throughout the year. Therefore, these municipalities were selected for the present study.

\footnotetext{
${ }^{*}$ Corresponding author

E-mail: herintha@yahoo.com.br (H.C. Neitzke-Abreu).
} 
Sandfly collection was carried out in the municipalities of Jaboti

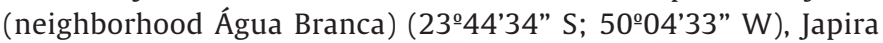

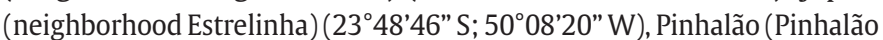
riverside) ( $\left.23^{\circ} 47^{\prime} 34^{\prime \prime} \mathrm{S} ; 50^{\circ} 03^{\prime} 21^{\prime \prime} \mathrm{W}\right)$, and Tomazina (neighborhood Germino) ( $23^{\circ} 46^{\prime} 40^{\prime \prime}$ S; $49^{\circ} 57^{\prime} 00^{\prime \prime}$ W) in the North Pioneer mesoregion of Paraná State in the Second Plateau, Eastern Landing of the Paraná Basin, at altitudes of 550 to 650 meters. The geological characteristics, climatology, hydrography, demography, type of vegetation, and form of land occupation have previously been described by Truppel et al. (2014).

For sandfly collection, Falcão light traps were used, once a month in each municipality, from Monday to Friday, in the second or third week, from 7 pm to 6 am from November 2007 to November 2008, for a total of 143 hours of collection per trap. The collections were made on different days of the week, considering that only two people performed them. In each of the locations, 10 traps were installed in the domicile (balcony of residences) and peridomicile (Figure 1), at a minimum distance of 5 meters. The collected sandflies were killed with chloroform, packed in small cardboard boxes, and identified and named according to Galati (2018).
To assess the abundance of the sandfly species, the Standardized Species Abundance Index (SISA) was used (Robert and His, 1979). For species diversity, the Shannon-Wiener Index $\left(\mathrm{H}^{\prime}\right)$ was used according to the formula $-\Sigma \operatorname{logn}$ (freqx) (Shannon and Weaver, 1949; Magurran, 1988). For the equitability of species, the Pielou Index (J) was used (Hayeck and Buzas, 1997). For species dominance, the Berger-Parker Index (Bp) was used (Berger and Parker, 1970; Magurran, 1988). To assess the similarity between sandfly fauna in the home and home environment, the Sorensen Index (S) was used (Sorensen, 1948). The species proportions were analyzed using the Mid-p exact test using OpenEpi version 2. Analyses of the frequency of sandflies in the different municipalities were carried out by analysis of variance (ANOVA), at the significance level of $5 \%$.

In total, 32,994 sandflies were collected in the four municipalities. In Jaboti 11,408 specimens were collected, in Japira 10,008, in Pinhalão 5,228 , and in Tomazina 6,350 (Table 1 ). Analysis of sandfly frequency showed that there was no significant difference in the number of sandflies collected in different municipalities $(\mathrm{p}=0.4909)$.

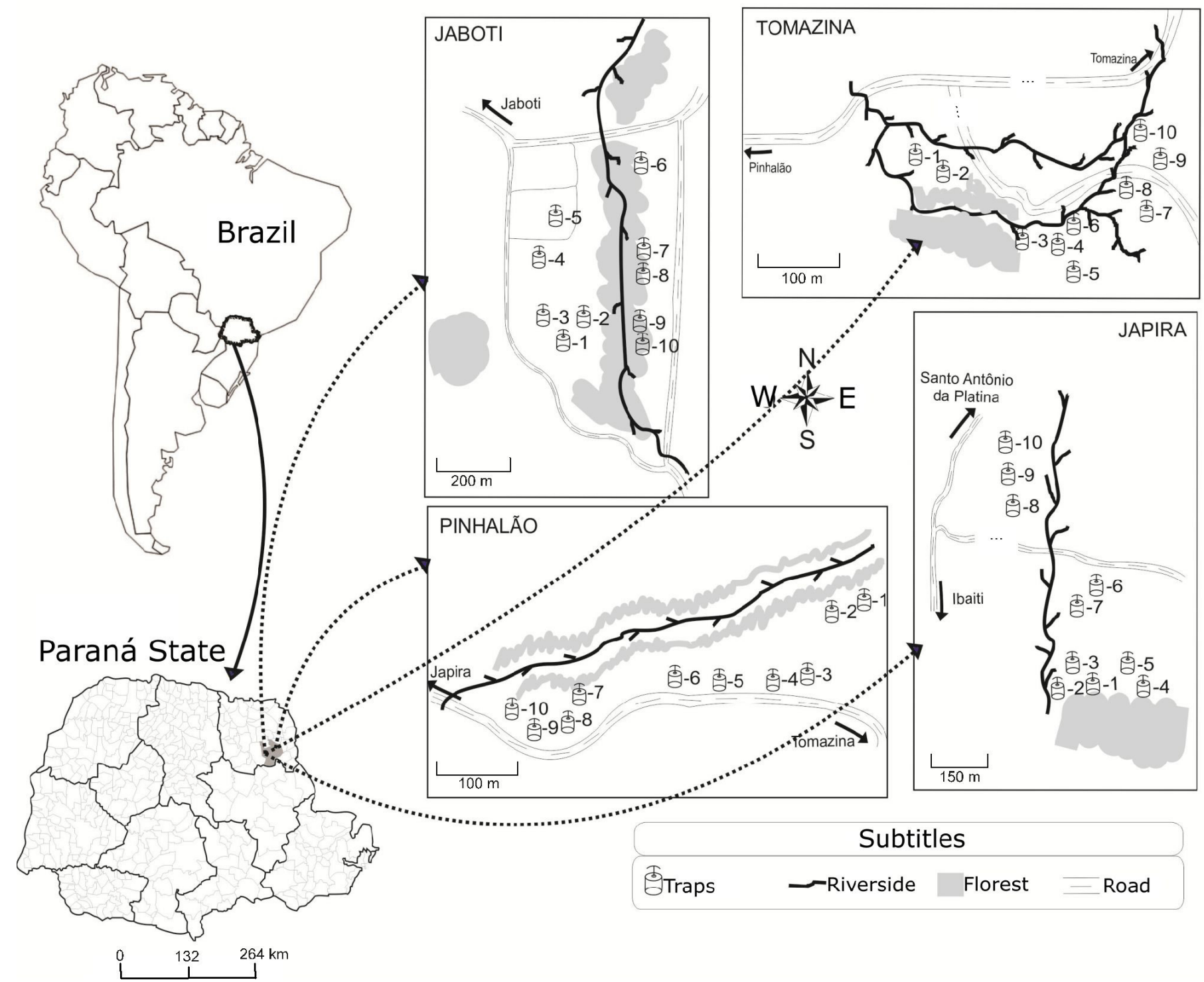

Figure 1 Geographic location of ecotopes in the locations where sandflies collections were carried out, in municipalities in the Northern Pioneer of the Paraná State, Brazil. 


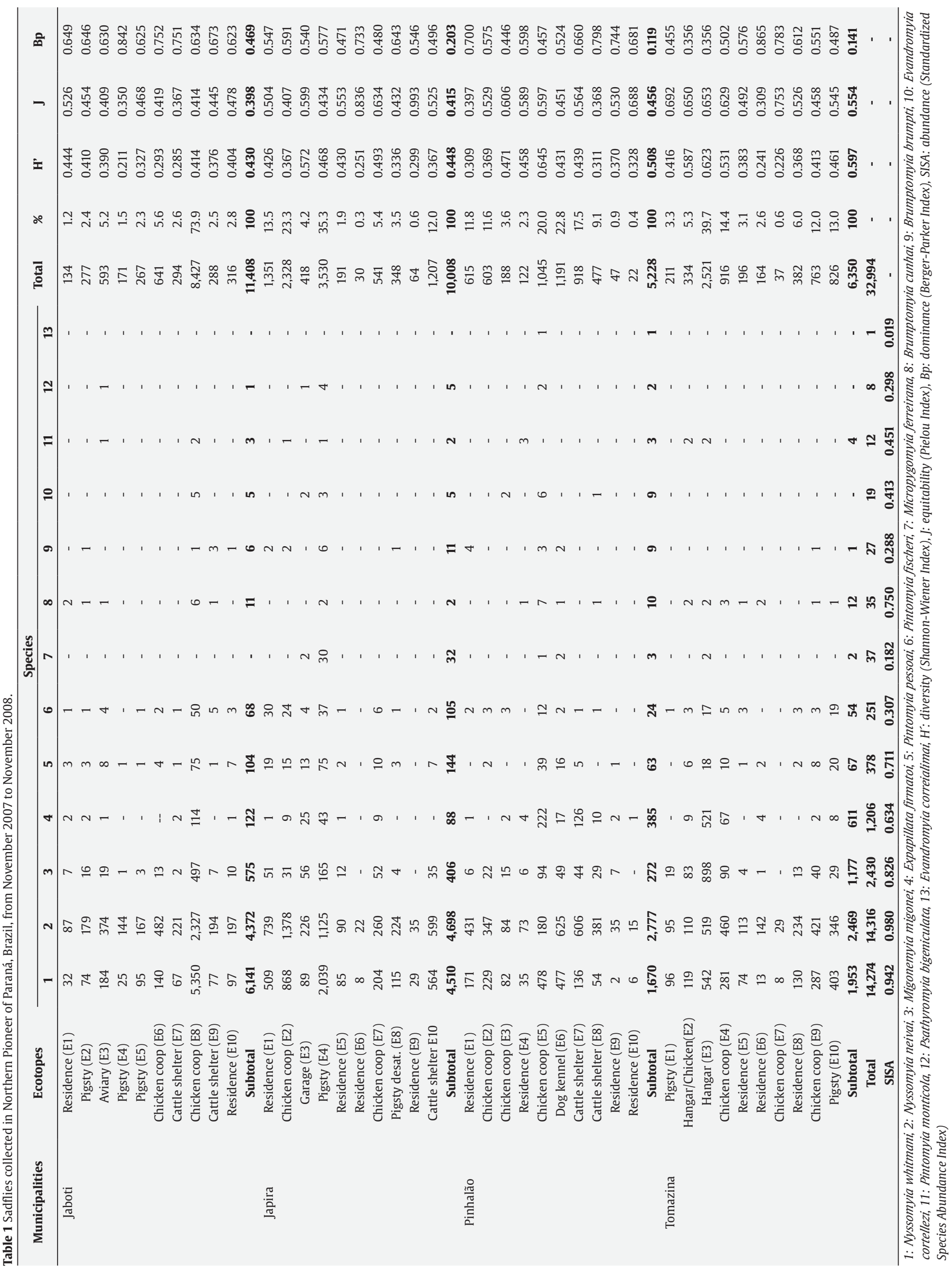


The species Brumptomyia brumpti(Larrousse), Brumptomyia cunhai (Mangabeira), Expapillata firmatoi (Barretto, Martins \& Pellegrino), Migonemyia migonei (França), Nyssomyia neivai (Pinto), Nyssomyia whitmani(Antunes \& Coutinho), Pintomyia fischeri( Pinto), Pintomyia monticola (Costa Lima), and Pintomyia pessoai (Coutinho \& Barretto) were common across the four municipalities. Evandromyia cortelezzii (Brèthes) and Psathyromyia bigeniculata(Dyar) were not only collected in Tomazina, Micropygomyia ferreirana (Barreto, Martins \& Pellegrino) was not collected only in Jaboti, and Evandromyia correalimai (Martins, Coutinho \& Luz) was collected only in Pinhalão (Table 1). All species identified in this study have already been registered in the State of Paraná (Membrive et al., 2004; Silva et al., 2008; Teodoro et al., 2010).

$N y$. neivai was the dominant species in Japira (46.9\%), Pinhalão (53.1\%), and Tomazina (38.9\%), while in Jaboti $N y$. whitmani(53.8\%) was dominant. Ny neivai (SISA = 0.9808), Ny. whitmani (SISA $=0.9423$ ), and Mi. migonei (SISA $=0.8269$ ) were the most prevalent and accounted for $94 \%$ of sandflies collected. These species have already been detected with natural infection by Leishmania (Pita-Pereira et al., 2005; Carvalho et al., 2010; Neitzke-Abreu et al., 2014) and play an important role in the epidemiology of CL in Paraná (Membrive et al. 2004; Silva et al., 2008; Teodoro et al., 2010) and other Brazilian states.

Ny. neivai and Ny. whitmani were the only species collected in all environments. The predominance of $\mathrm{Ny}$. neivai in most ecotopes indicates the adaptation of this species in areas with intense anthropic action (Aguiar and Medeiros, 2018). Ny. whitmani predominated in ecotopes on the margins of or inside the forest, as previously reported (Aguiar and Medeiros, 2018). Mi. migonei, incriminated as a vector for Leishmania braziliensis (Rangel \& Lainson, 2009), predominated in a hangar located eight meters from a residence in Tomazina. This species resists drastic environmental changes, adapting easily in and around human habitations (Aguiar and Medeiros, 2018). Ex. firmatoi was the fourth most collected species and, although not common, it was generally found in shelters for domestic animals and on the margins of forests (Aguiar and Medeiros, 2018). The species M. ferreirana, L. cortelezzii, and Pa. bigeniculata were collected only in the domicile.

The proportion of males [55.89; 95\% CI (Confidence Interval), $55.36-56.43 ; 18,442$ specimens] was higher than that of females (44.11; 95\% CI, 43.57-44.64; 14,552 specimens). This may be because females hatch later than males (Kelly and Dye, 1997), besides the fact that the light trap can influence the highest proportion of males (Rosario et al., 2017).

The hourly average of sandflies collected in the peridomicile was significantly higher than in the domicile $(\mathrm{p}=0.0017)$. The majority of sandflies were collected in chicken coops, cattle shelters, dog kennels, and hangars, indicating the affinity of these insects for domestic animals. In Tomazina, most sandflies were collected in a cattle shed, where rodents were attracted by stored corn. The areas in and around domestic animal shelters have favorable conditions for breeding sites of sandflies due to the accumulation of organic matter (food scraps, feces, etc.) and high humidity (Reinhold-Castro et al., 2015). Domestic animal shelters are usually located several meters from the main houses, favoring the invasion of the home by sandflies and increasing the risk of infection by Leishmania (Membrive et al., 2004; ReinholdCastro et al., 2008). The infection of Equidae (Truppel et al., 2014) in the studied municipalities indicates that domestic animals may play a fundamental role in maintaining the Leishmania cycle in peridomiciles.

There was a greater diversity of species in Tomazina (0.5978) followed by Pinhalão (0.5088). Species diversity was higher in the home environment in Japira, Pinhalão, and Tomazina, while in Jaboti it was higher in the domicile. The equitability of the species was greater in Tomazina (0.5540) followed by Pinhalão (0.4568). The greatest dominance of species occurred in Jaboti $(0.4690)$ (Table 1$)$. The similarities between sandfly fauna in the domicile and peridomicile were stronger in Jaboti (0.8421), followed by Tomazina (0.8235), Pinhalão (0.7619), and Japira (0.7368).

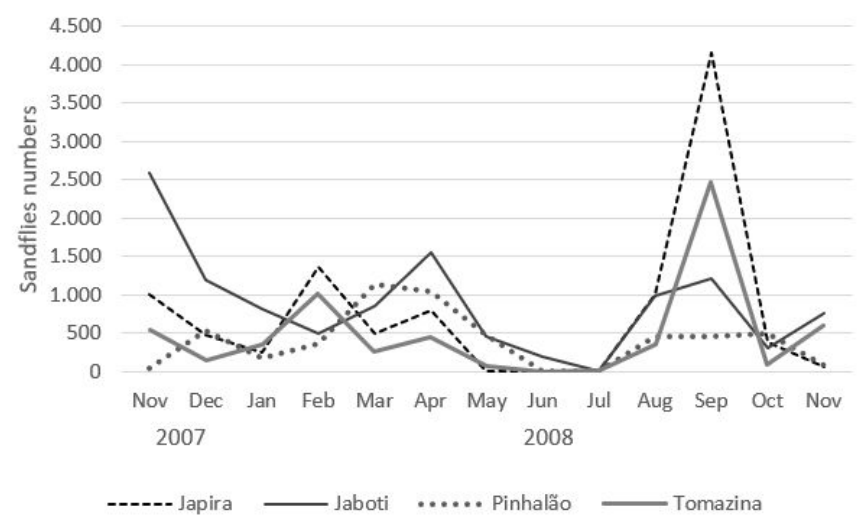

Figure 2 Monthly frequency of sandflies collected in municipalities in Northern Pioneer of Paraná, Brazil, from November 2007 to November 2008.

The greatest abundance of sandflies occurred in November 2007 and April and September 2008 (Figure 2), hot and humid months after peaks of rainfall. Abiotic factors interfere in the evolutionary cycle of sandflies, altering their reproduction. In general, high rainfall and relative humidity are favorable for insect population growth (ReinholdCastro et al., 2015). Thus, it was found that the highest frequency of sandflies was reported in the rainy season (Reinhold-Castro et al., 2008; Almeida et al., 2013), while in the cold and dry months, there is a reduction in the frequency of these insects (Silva et al., 2008).

The high number of sandflies collected, richness of species, occurrence of $120 \mathrm{CL}$ cases between 2001 and 2018 in the cities in question, presence of domestic animals with Leishmania in the peridomicile and in wild reservoirs, and the presence of important sandfly species in the epidemiology of CL reveal the need for permanent entomological surveillance in the municipalities where this study was conducted. Environmental changes due to anthropogenic actions result in changes in sandfly fauna and behavior, with an increase in the frequency of these insects in the peridomicile, close to homes. The "modus vivendi" of man may be a strong aggravating factor in the transmission of Leishmania in anthropic environments, thus, when considering measures to control $\mathrm{CL}$, the findings of the present study should be considered.

\section{Acknowledgments}

We would like to thank the Conselho Nacional de Desenvolvimento Científico e Tecnológico [grant number 410550/2006-0] for the financial support.

\section{Conflicts of interest}

The authors declare no conflicts of interest.

\section{Author contribution statement}

All authors conceived the research. The first and second authors wrote the first version of the manuscript and all authors contributed reviewing critically the manuscript for important content. All authors approved the final version of this paper.

\section{References}

Aguiar, G. M., Medeiros, W. M., 2018. Regional distribution and habitats of brazilian phlebotomine species. In: Rangel, E.F., Shaw, J.J. (Eds.), 
Brazilian Sand Flies: Biology, Taxonomy, Medical Importance and Control. Editora Springer, Rio de Janeiro, pp. 251-298.

Almeida, P. S., Leite, J. A., Araújo, A. D., Batista, P. M., Touro, R. B. S., Araújo, V. S., Souza, E. J., Rodrigues, J. B., Oliveira, G. A., Santos, J. V., Faccenda, O., Andrade Filho, J. D., 2013. Fauna of phlebotomine sand flies (Diptera, Psychodidae) in areas with endemic American cutaneous leishmaniasis in the State of Mato Grosso do Sul, Brazil. Rev. Bras. Entomol. 57, 105-112.

Berger, W. H., Parker, F. L., 1970. Diversity of planktonic foraminifera in deep-sea sediments. Science 168 (3937), 1345-1347.

Brasil, Ministério da Saúde, 2018. Casos de Leishmaniose Tegumentar Americana. Brasil, Grandes Regiões e Unidades Federadas, de 1990 a 2017. Available in: http://portalarquivos2.saude.gov.br/images/ pdf/2018/novembro/12/LT-Casos.pdf (accessed 15 April 2020).

Carvalho, M. R., Valença, H. F., Silva, F. J., Pita-Pereira, D., Araújo Pereira, T. A., Britto, C., Brazil, R. P., Brandão-Filho, S. P., 2010. Natural Leishmania infantum infection in Migonemyia migonei (França, 1920) (Diptera: Psychodidae: Phlebotominae) the putative vector of visceral leishmaniasis in Pernambuco State, Brazil. Acta Trop. $116,108-110$.

Galati, E. A. B., 2018. Phlebotominae (Diptera, Psychodidae): classification, morpholog and terminology of adults and identification of american taxa. In: Rangel, E.F., Shaw, J.J. (Eds.), Brazilian Sand Flies: Biology, Taxonomy, Medical Importance and Control. Editora Springer, Rio de Janeiro, pp. 9-212.

Hayeck, L. A. C., Buzas, M. A., 1997. Surveying Natural Populations. Columbia University Press, New York, pp. 347-389.

Kelly, D. W., Dye, C., 1997. Pheromones, kairomones and the aggregation dynamics of the sandfly Lutzomyia longipalpis. Anim. Behav. 53, 721-731.

Lima, A. P., Minelli, L., Teodoro, U., Comunello, E., 2002. Distribuição da leishmaniose tegumentar por imagens de sensoriamento remoto orbital, no estado do Paraná, sul do Brasil. An. Bras. Dermatol. 77, 681-692.

Magurran, A. E., 1988. Ecological Diversity and Measurement. New Fatter Lane, London, pp. 1-179.

Membrive, N. A., Rodrigues, G., Membrive, U., Monteiro, W. M., Neitzke, H. C., Lonardoni, M. V. C., Silveira, T. G. V., Teodoro, U., 2004. Flebotomíneos de municípios do norte do estado do Paraná, sul do Brasil. Entomol. Vectores 11, 673-680.

Muniz, L. H. G., Rossi, R. M., Neitzke, H. C., Monteiro, W. M., Teodoro, U., 2006. Estudo dos hábitos alimentares de flebotomíneos em área rural no sul do Brasil. Rev. Saude Publica 40, 1087-1093.

Neitzke-Abreu, H. C., Reinhold-Castro, K. R., Venazzi, M. S., Scodro, R. B. L., Dias, A. C., Silveira, T. G. V., Teodoro, U., Lonardoni, M. V. C., 2014. Detection of Leishmania (Viannia) in Nyssomyia neivai and Nyssomyia whitmani by multiplex polymerase chain reaction, in Southern Brazil. Rev. Inst. Med. Trop. São Paulo 56, 391-395.

Pita-Pereira, D., Alves, C. R., Souza, M. B., Brazil, R. P., Bertho, A. L., Figueiredo-Barbosa, A., Britto, C. C., 2005. Identification of naturally infected Lutzomyia intermedia and Lutzomyia migonei with Leishmania (Viannia) braziliensis in Rio de Janeiro (Brazil) revealed by a PCR multiplex non-isotopic hybridisation assay. Trans. R. Soc. Trop. Med. Hyg. 99, 905-913.

Rangel, E. F., Lainson, R., 2009. Proven and putative vectors of American cutaneous leishmaniasis in Brazil: aspects of their biology and vectorial competence. Mem. Inst. Oswaldo Cruz 104, 937-954.

Reinhold-Castro, K. R., Gasparotto, J. C., Neitzke-Abreu, H. C., Teodoro, U., 2015. Larval habitats of sand flies in rural areas of southern Brazil. J. Vector Ecol. 40, 269-276.

Reinhold-Castro, K. R., Scodro, R. B. L., Dias-Sversutti, A. C., Neitzke, H. C., Rossi, R. M., Kühl, J. B., Silveira, T. G. V., Teodoro, U., 2008. Avaliação de medidas de controle de flebotomíneos. Rev. Soc. Bras. Med. Trop. 41, 269-276.

Robert, D. R., His, B. P., 1979. An index of species abundance for use with mosquito surveillance data. Environ. Entomol. 8 (6), 1007-1013.

Rosario, I. N. G., Andrade, A. J., Ligeiro, R., Ishak, R., Silva, I. M., 2017. Evaluating the adaptation process of sandfly fauna to anthropized environments in a leishmaniasis transmission area in the Brazilian Amazon. J. Med. Entomol. 54, 450-459.

Shannon, C. E., Weaver, W., 1949. The Mathematical Theory of Communication. The University of Illinois Press, Urbana, Illinois, pp. 1-117.

Silva, A. M., Camargo, N. J., Santos, D. R., Massafera, R., Ferreira, A. C., Postai, C., Cristóvão, E. C., Konolsaisen, J. F., Bisetto, J. R. A., Perinazo, R., Teodoro, U., Galati, E. A. B., 2008. Diversity, distribution and abundance of sandflies (Diptera: Psychodidae) in Paraná state, southern Brazil. Neotrop. Entomol. 37, 209-225.

Sorensen, T., 1948. A method of establishing groups of equal amplitude in plant sociology based on similarity os species conten and its application to analyses of the vegetation on Danish commons. Biol. Skr. 5, 1-34.

Teodoro, U., Kühl, J. B., Abbas, M., Dias, A. C., 2001a. Luz e aves como atrativos de flebotomíneos (Diptera, Psychodidae), no sul do Brasil. Rev. Bras. Entomol. 45, 167-172.

Teodoro, U., Silveira, T. G. V., Santos, D. R., Santos, E. S., Santos, A. R., Oliveira, O., Kühl, J. B., 2001b. Frequência da fauna de flebotomíneos no domicílio e em abrigos de animais domésticos no peridomicílio, nos municípios de Cianorte e Doutor Camargo - Estado do Paraná - Brasil. Rev. Patol. Trop. 30, 209-233.

Teodoro, U., Santos, D. R., Silva, A. M., Massafera, R., Imazu, L. E., Monteiro, W. M., Neitzke-Abreu, H. C., 2010. Fauna de flebotomíneos em municípios do norte pioneiro do estado do Paraná, Brasil. Rev. Patol. Trop. 39, 322-330.

Truppel, J. H., Otomura, F., Teodoro, U., Massafera, R., Costa-Ribeiro, M. C. V. D., Catarino, C. M., Dalagrana, L., Ferreira, M. E. M. C., ThomazSoccol, V., 2014. Can equids be a reservoir of Leishmania braziliensis in endemic areas? PLoS One 9, e93731. 